\title{
The calcium sensing receptor: from calcium sensing to signaling
}

\author{
ZHANG Chen ${ }^{1,2}$, MILLER Cassandra Lynn ${ }^{1}$, BROWN Edward $\mathrm{M}^{3}$ \& YANG Jenny J. ${ }^{1,2 *}$ \\ ${ }^{1}$ Department of Chemistry, Georgia State University, Atlanta, Georgia 30303, USA; \\ ${ }^{2}$ Center for Diagnostics and Therapeutics, Georgia State University, Atlanta, Georgia 30303, USA; \\ ${ }^{3}$ Division of Endocrinology, Diabetes and Hypertension, Department of Medicine, Brigham and Women's Hospital, Boston, MA 02115, USA
}

Received August 17, 2014; accepted October 21, 2014

\begin{abstract}
The $\mathrm{Ca}^{2+}$-sensing receptor (the CaSR), a G-protein-coupled receptor, regulates $\mathrm{Ca}^{2+}$ homeostasis in the body by monitoring extracellular levels of $\mathrm{Ca}^{2+}\left(\left[\mathrm{Ca}^{2+}\right]_{0}\right)$ and responding to a diverse array of stimuli. Mutations in the $\mathrm{Ca}^{2+}$-sensing receptor result in hypercalcemic or hypocalcemic disorders, such as familial hypocalciuric hypercalcemia, neonatal severe primary hyperparathyroidism, and autosomal dominant hypocalcemic hypercalciuria. Compelling evidence suggests that the CaSR plays multiple roles extending well beyond not only regulating the level of extracellular $\mathrm{Ca}^{2+}$ in the human body, but also controlling a diverse range of biological processes. In this review, we focus on the structural biology of the CaSR, the ligand interaction sites as well as their relevance to the disease associated mutations. This systematic summary will provide a comprehensive exploration of how the CaSR integrates extracellular $\mathrm{Ca}^{2+}$ into intracellular $\mathrm{Ca}^{2+}$ signaling.
\end{abstract}

the $\mathrm{Ca}^{2+}$-sensing receptor (the CaSR), $\mathrm{Ca}^{2+}$ signaling, extracellular domain (ECD), $\mathrm{Ca}^{2+}$-binding sites

Citation: Zhang C, Miller CL, Brown EM, Yang JJ. The calcium sensing receptor: from calcium sensing to signaling. Sci China Life Sci, 2015, 58: 14-27, doi: $10.1007 / \mathrm{s} 11427-014-4779-\mathrm{y}$

After Sydney Ringer serendipitously discovered calcium $\left(\mathrm{Ca}^{2+}\right)$ to be essential for the contraction of isolated hearts in 1883 [1], $\mathrm{Ca}^{2+}$ has received substantial attention and research on $\mathrm{Ca}^{2+}$ has grown at an exponential rate as it was recognized that $\mathrm{Ca}^{2+}$ is a universal carrier of biological information [2]. $\mathrm{Ca}^{2+}$ controls matters of life and death as it modulates the process of fertilization as well as apoptosis.

Before the discovery of the calcium-sensing receptor (the CaSR), $\mathrm{Ca}^{2+}$ was mainly considered as a crucial second messenger through rapid yet efficient alterations in the intracellular calcium; it modulates extensive molecular signaling components through calcium channels and exchangers as well as pumps [3]. When $\mathrm{Ca}^{2+}$ plays a role as first messenger for the CaSR, it integrates calcium signaling from changes in the extracellular $\mathrm{Ca}^{2+}$ concentration $\left(\left[\mathrm{Ca}^{2+}\right]_{0}\right)$ to intracellular signaling networks that are criti-

*Corresponding author (email: jenny@gsu.edu) cally important for many (patho)physiological processes, including cardiovascular remodeling, tumor cell migration and cancer metastasis [4-7]. $\mathrm{Ca}^{2+}$-sensing receptors (the CaSRs) along with 14 other members of family $\mathrm{C}$ of the $\mathrm{G}$ protein-coupled receptors (cGPCRs), i.e., the metabotropic glutamate receptors (mGluR) and $\gamma$-aminobutyric acid $(\mathrm{GABA})_{\mathrm{B}}$ receptors, cooperatively respond to small changes in $\left[\mathrm{Ca}^{2+}\right]_{0}$ to activate multiple signaling pathways. The cGPCRs are also integrators of diverse extracellular signaling molecules, including metabolites neurotransmitters (i.e., amino acids), pheromones, and sweet substances using their conserved long N-terminal extracellular domains (ECD) with a Venus Fly Trap (VFT) motif that contains a flexible hinge region. The CaSRs distributed in multiple organs play a central role in regulating $\left[\mathrm{Ca}^{2+}\right]_{\mathrm{o}}$ homeostasis $[8-12]$ as well as monitoring protein/amino acid metabolism by sensing amino acids, especially aromatic amino acids, in blood and related extracellular fluids. 
Although $\mathrm{Ca}^{2+}$ is considered as a universal signal for the regulation of cells, it can be toxic to cells if it stays too long at an excessively high concentration. Pulsatile $\mathrm{Ca}^{2+}$ signals have evolved to prevent such toxicity. Two major mechanisms are involved in the production of the temporal $\mathrm{Ca}^{2+}$ signals that can, in turn, lead to more complex downstream signaling. The first one happens in skeletal and cardiac cells when the intracellular $\mathrm{Ca}^{2+}$ signaling pulses are produced on demand as the cells respond to periodic stimulation that leads to membrane depolarization. This kind of signal can be observed in muscle cells when they contract and also in nerve terminals when neurotransmitters are released upon a brief localized pulse of intracellular $\mathrm{Ca}^{2+}$ [2]. The second type appears as an oscillation when the cells receive continuous stimulation over a period of time. This rhythmic $\mathrm{Ca}^{2+}$ signal has a wide range of frequencies that are tightly related to a variety of cellular responses (i.e., gene expression, fertilization, cell growth, transmitter release, etc.) [13].

In this review, we will review the structural information known about the CaSR and explore its molecular properties as an important therapeutic target in disorders with abnormal $\left[\mathrm{Ca}^{2+}\right]_{0}$ homeostasis.

\section{Biological roles of the CaSR}

It has been well known that the serum $\mathrm{Ca}^{2+}$ concentration can regulate the secretion of parathyroid hormone (PTH). In 1993, Dr. Edward M. Brown and coworkers [14] cloned the receptor that is primarily responsible for this type of regulation from the bovine parathyroid gland. The receptor was given the name "calcium-sensing receptor" (the CaSR/CaR). The previously observed cytosolic calcium changes in parathyroid cells, as well as in other in vitro expression systems, were triggered by changes in the serum calcium concentration and are characteristic "signatures" of the CaSR's activities $[15,16]$. A unique characteristic of the CaSR is the high degree of cooperativity of its $\mathrm{Ca}^{2+}$-dependent activation, which tightly controls the secretion of parathyroid hormone when the receptor is exposed to changes in serum $\mathrm{Ca}^{2+}$ concentration within its responsive range [14]. The CaSRs expressed in various species are highly conserved, indicating the biological importance of this receptor in regulating physiological functions among living organisms.

The major function of the CaSR is to maintain calcium homeostasis through balancing the ingestion and absorption of calcium from the gastrointestinal tract, excretion of calcium by the urinary system and the breakdown and formation of bone [17,18] (Figure 1). The CaSR is mainly expressed in the parathyroid and thyroid glands, as well as in other tissues mentioned above. The CaSR regulates PTH secretion from parathyroid glands and calcitonin secretion from thyroidal $\mathrm{C}$-cells upon detection of variations in the calcium concentration in the extracellular fluid [17].

Moreover, the CaSR has its specific roles in different tissues. As mentioned in the last section, the CaSR was first discovered in parathyroid cells. The main function of the receptor is to mediate the negative feedback of PTH secretion upon stimulation by various agonists [14]. Most of the CaSR expressed in parathyroid cells is located in caveolae, where a significant number of signaling molecules, as well as scaffolding proteins, reside [19]. Similarly, one of the critical roles the CaSR expressed in the kidney is in maintaining calcium homeostasis [20]. However, the CaSR along different parts of the nephron (e.g., the proximal tubule, thick ascending limb, etc.) may have specific functions $[21,22]$.

The CaSR is also found in the gastrointestinal tract, including the esophagus, stomach, small intestine, and colon $[23,24]$. The activity of the CaSR has been reported to be associated with increased phosphorylation of ERK, intra-

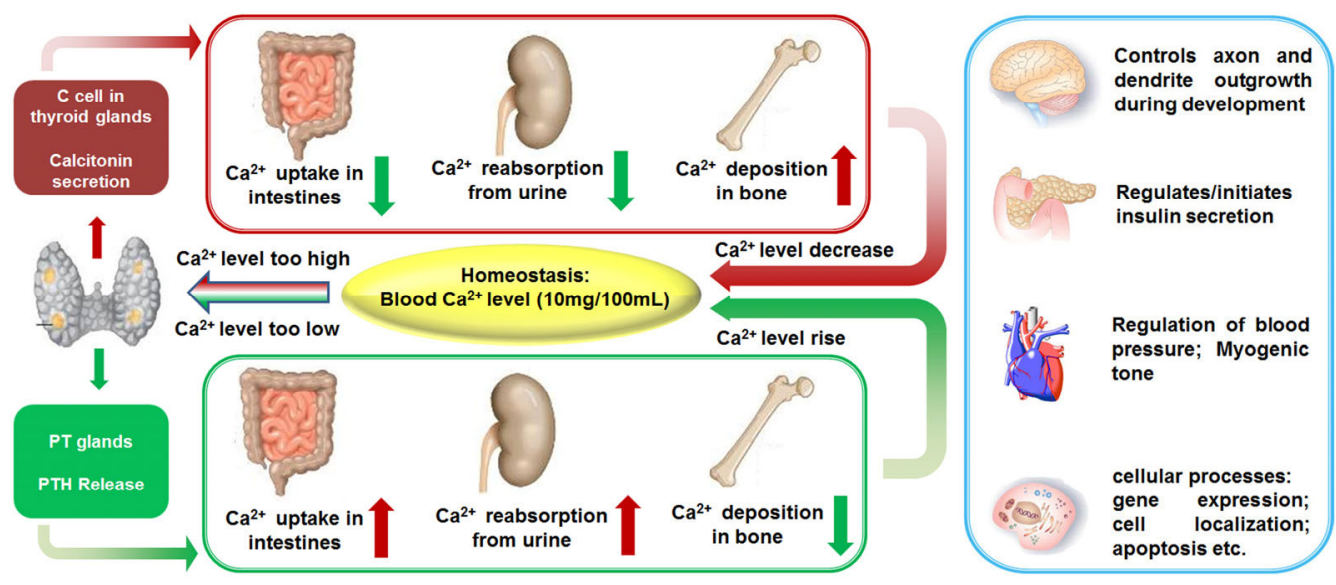

Figure 1 Systematic regulation of $\mathrm{Ca}^{2+}$ homeostasis in human body. Two major circulating hormones (PTH and CT) regulate Ca ${ }^{2+}$ homeostasis via several primary organs. If the $\mathrm{Ca}^{2+}$ level is too low, $\mathrm{PTH}$ is released from parathyroid glands. It then stimulates $\mathrm{Ca}^{2+}$ uptake from intestines, increases the rate of $\mathrm{Ca}^{2+}$ release from bone and the rate of $\mathrm{Ca}^{2+}$ reabsorption in the urinary system. If the $\mathrm{Ca}^{2+}$ level is too high, the opposite regulation will occur to control the blood $\mathrm{Ca}^{2+}$ level. Thus, the blood $\mathrm{Ca}^{2+}$ is strictly maintained between $1.1-1.4 \mathrm{mmol} \mathrm{L}$. 
cellular calcium mobilization, secretion of IL-8, gastric acid [25-27] and cell proliferation and differentiation [28,29].

The CaSR has been identified in bone as demonstrated by various techniques [30]. Both osteoblasts and osteoblastic cell lines, such as MC3T3-E1 cells, as well as osteoclasts are reported to express the CaSR. The receptor is involved in osteoblast proliferation, likely via JNK signaling [31,32], and participates in both differentiation and apoptosis of osteoclasts through the PLC pathway [33]. Activation of the CaSR is also believed to inhibit the bone resorbing activity of osteoclasts [34].

Experiments using immunocytochemistry showed that the CaSR is widely distributed in the central nervous system with quite a diverse pattern [35]. In the nervous system, the CaSR can also form heterodimers with other family $\mathrm{C}$ GPCRs [36,37]. It has been proposed that the CaSR may play a crucial role in regulating ion currents that mediate the initiation of action potentials and the associated neuronal depolarization [38]. The CaSR in the hippocampus has been reported to regulate both $\mathrm{Ca}^{2+}$-permeable, nonselective cation channels as well as $\mathrm{Ca}^{2+}$-activated $\mathrm{K}^{+}$channels $[35,39,40]$.

The CaSR is also detected in cardiac tissue by various techniques, including RT-PCR and immunohistochemistry [41]. A few pathological processes have been found to be associated with an increased expression level of the CaSR, for instance, angiotensin II-induced cardiac hypertrophy [42] and hypoxic-oxygenation-treated cardiac myocytes [43].

\section{The structural biology of the CaSR}

The CaSR expressed in pcDNA-CaSR-transfected human embryonic kidney (HEK293) cells exhibits similar expression patterns as the CaSR proteins identified in parathyroid cells [44]. The Western blot results of the CaSR extracted from HEK293 cells showed several immunoreactive bands using antibodies specific for the CaSR. The minor band at $120 \mathrm{kD}$ corresponds to the non-glycosylated monomeric form of the protein, the major band at $140 \mathrm{kD}$ is the high mannose form, while another major band at $160 \mathrm{kD}$ represents the complex carbohydrates form of the monomeric CaSR $[44,45]$. Additional bands at higher molecular mass $(350 \mathrm{kD})$ correspond to the dimeric forms of the receptor. The CaSR that is expressed on the cell membrane is the mature receptor that only accounts for a small portion of the total cellular protein [46].

The CaSR comprises four major parts in terms of its structure: a large $\mathrm{N}$-terminal extracellular domain (ECD), a cysteine-rich domain linking the ECD to the first transmembrane helix, a seven transmembrane domain and the intracellular C-terminal. The major function of the CaSR in vivo is regulating the calcium concentration in the human blood. Upon stimulation with $\mathrm{Ca}^{2+}$ or other polycations, a number of intracellular signal transduction pathways are activated (Figure 2). Among them, the phosphoinositidespecific phospholipase C (PI-PLC) and extracellular signal-regulated kinases (ERK1/2) have been widely applied to the investigation of CaSR activity $[48,49]$.

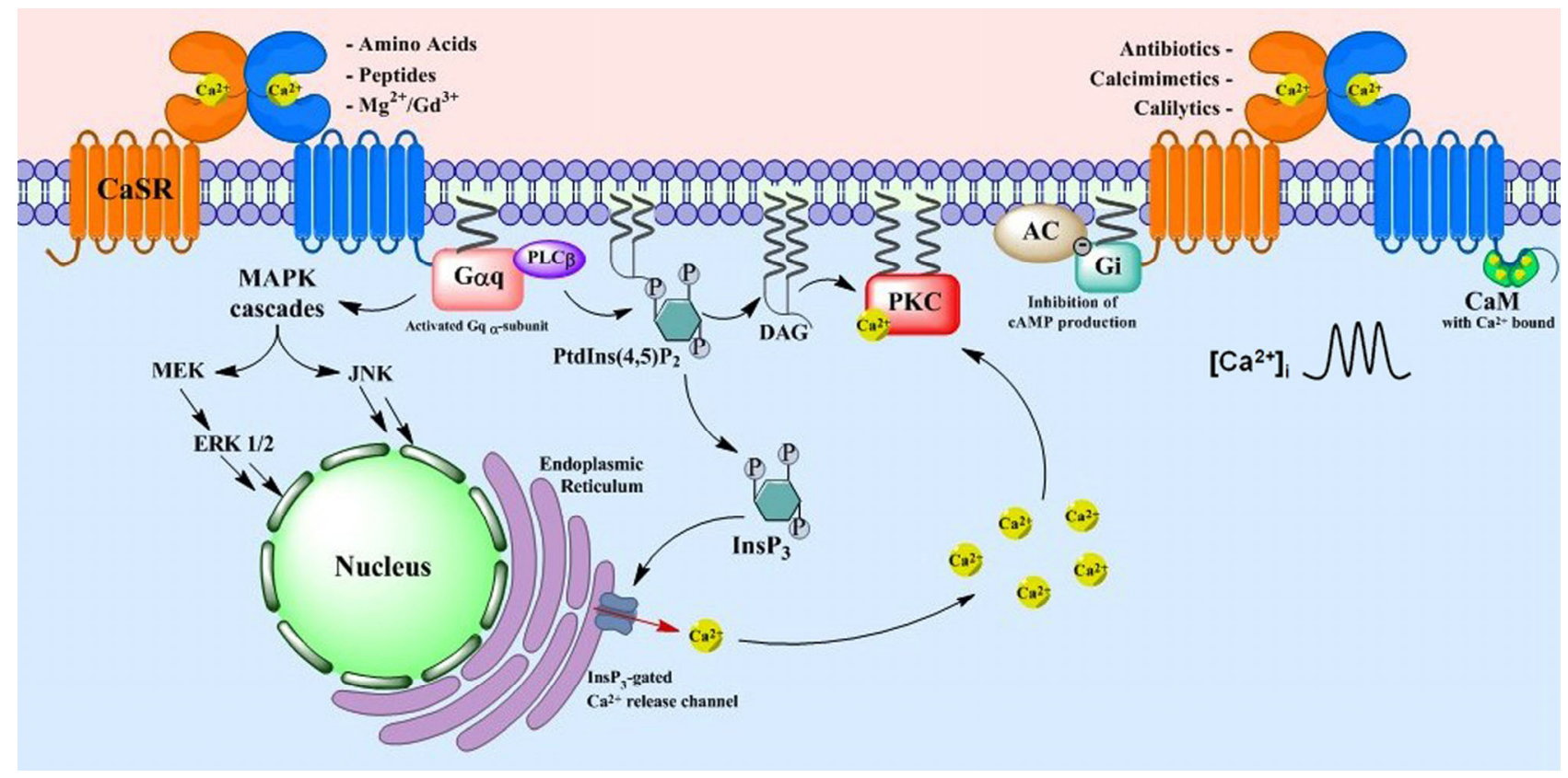

Figure 2 Calcium-sensing receptor-regulated intracellular signaling pathways. The interaction between $\mathrm{Ca}^{2+}$ and CaSR results in activation of phosphatidylinositol-specific phospholipase $\mathrm{C}_{\beta}\left(\mathrm{PLC}_{\beta}\right)$ through recruitment of the $\mathrm{G}_{\alpha \mathrm{q} / 11}$ proteins. PLC $\mathrm{C}_{\beta}$ hydrolyzes phosphatidylinositol-4,5-bisphosphate [PtdIns $\left.(4,5) \mathrm{P}_{2}\right]$ to inositol-1,4,5-trisphosphate $\left(\mathrm{InsP}_{3}\right)$ and diacylglycerol (DAG). Ins $\mathrm{P}_{3}$ triggers the release of calcium from the endoplasmic reticulum (ER) calcium store via the $\mathrm{InsP}_{3}$ receptor $\left(\mathrm{IP}_{3} \mathrm{R}\right)$ embedded in the ER membrane. Calmodulin $(\mathrm{CaM})$ binds to the C-terminus of CaSR to maintain proper responsiveness of intracellular $\mathrm{Ca}^{2+}$ responses to changes in extracellular $\mathrm{Ca}^{2+}$ and regulate cell surface expression of the receptor [47]. 
Like other members in the family C GPCR proteins, the CaSR possesses the signature large $\mathrm{N}$-terminal ECD. The low but significant amino acid sequence identity between the family C GPCRs and a group of bacterial periplasmic amino acid-binding proteins suggest evolutionary relevance. Indeed, the crystal structure of the ECD of rat metabotropic glutamate receptor (mGluR1) showed a bi-lobed Venus-flytrap-like structure (VFT), which is fully consistent with the structure of the bacterial periplasmic amino acid-binding proteins, switching between "open" and "closed" conformational states upon releasing or binding their endogenous agonists (Figure 3A) [50]. The alignment of the amino acid sequence of the CaSR ECD (AA36-AA513) with mGluRs and the bacterial periplasmic amino acidbinding proteins results in a proposed VFT model of the CaSR ECD with the N-terminal lobe I connecting to the C-terminal lobe II [51]. However, the alignment also shows four segments in lobe I that do not align with the bacterial periplasmic amino acid-binding protein resulting in four unstructured loops (I-IV) [52]. Only a large part of loop III (from residues 365-385) could be deleted without reducing the activity of the CaSR while truncation in the other four loops resulted in a low surface expression of the receptor [52].

The VFT structure of mGluR1 forms a homodimer as verified by the $3 \mathrm{D}$ structure of rat mGluR1 VFT. The intermolecular disulfide requires a conserved cysteine in loop 2 , and the equivalent residues in the CaSR are C129 and C131 [51,53]. Experiments mutating the two cysteines suggested that disruption resulted in failure to form disulfide bonds, but did not affect the formation of dimer [54]. Other cysteines in the ECD of the CaSR including C60-C101, C358-C395 and C437-C449 form three intramolecular disulfides, which are critical for the CaSR expression and activity [55].

All members of the GPCR family $\mathrm{C}$ have a conserved nine-cysteine structure at the end of the C-terminal domain of the ECD and before the seven transmembrane domains except the $\mathrm{GABA}_{\mathrm{B}}$ receptor [56]. For the CaSR, the region possesses about 84 residues. Mutations of any of the nine Cys to Ser dramatically impair the surface expression and the function of the CaSR. Deletion of this Cys-rich domain results in the abrogation of the CaSR activity.

The CaSR contains a seven transmembrane domain (7TM) similar to the other proteins in the GPCR superfamily. It is believed that agonist binding to GPCRs will lead to conformational changes of the 7TM $\alpha$-helices, further inducing alterations in intracellular loops as well as the C-terminal domain, thereby triggering the downstream signaling pathways. The crystal structure of rhodopsin (a GPCR Family A protein), which has a 7TM domain like the GPCRs, has been reported. However, extreme caution is needed when extrapolating the CaSR 7TM structure from rhodopsin as proteins from family $\mathrm{C}$ share low sequence identity with proteins from family A. The six prolines in the transmembrane domain are important to maintain the kinks in the transmembrane helices. Mutations of some prolines (P748R, P823A) [57,58] impair receptor function.

The intracellular domain of the CaSR contains 216 amino acids that do not show high conservation among species [59]. Two regions in this intracellular tail are homologous between species: one from 863-925 located at the proximal of C-tail that is pivotal in surface expression; the other from 960-984 that is involved in interacting with downstream proteins [60-62]. Three potential protein kinase C (PKC) phosphorylation sites are present in the intracellular domain: T888, S895 and S915 are involved in regulating receptor activity [63]. Especially, T888 plays a significant role in the negative regulation of the CaSR's activity by PKC.

Along with the PKC phosphorylation sites, two other residues participate in protein kinase A phosphorylation: S899 and S900. Studies of these two sites indicate minor effects of PKA phosphorylation on the modulation of the CaSR activity [64], but the phosphorylation at S899 may regulate the recognition of an arginine-rich region in the proximal carboxyl terminus of the CaSR, which contributes to intracellular retention of the receptor [65].

\section{The ligand binding sites on the CaSR}

\subsection{Prediction of $\mathrm{Ca}^{2+}$-binding sites in the CaSR}

The identification of potential $\mathrm{Ca}^{2+}$ binding sites on the CaSR is challenging not only because of the lack of a crystal or solution structure of the receptor but also owing to the limitations of current techniques regarding direct measurement of $\mathrm{Ca}^{2+}$ binding to the receptor. The fast off rate of $\mathrm{Ca}^{2+}$ due to its weak binding affinity also hinders the characterization, as even with proteins that have their crystal structure solved (e.g., mGluR1), the detection of $\mathrm{Ca}^{2+}$ binding sites may still be elusive [66]. Our lab as well as a few other groups have generated homology model structures of the extracellular domain of the CaSR based on the crystal structures of mGluR1, and have identified predicted $\mathrm{Ca}^{2+}$-binding sites using these models $[67,68]$. One of the predicted $\mathrm{Ca}^{2+}$-binding sites has been proposed by both our group [69] and Silve et al. [67]. This $\mathrm{Ca}^{2+}$-binding site, later referred to as Site 1, is located in the hinge region between lobe I and lobe II of the CaSR ECD, and is composed of residues Ser147, Ser170, Asp190, Tyr218 and Glu297. Mutations of these five residues on the receptor resulted in impaired receptor function demonstrated by both groups. In our first paper about the CaSR, we also identified two additional $\mathrm{Ca}^{2+}$ binding sites using grafting approaches. One of them is located in lobe I, containing residues Glu378, Glu379, Thr396, Asp398 and Glu 399, and is referred to as Site 5 in the latter studies. The other one is on lobe II, involving resides Glu224, Glu228, Glu229, Glu231 and Glu232, which is named Site 3. Peptide sequences of the CaSR containing these predicted $\mathrm{Ca}^{2+}$ binding site were 
inserted into CD2 protein. The latter is known as a non $\mathrm{Ca}^{2+}$-binding protein, and the chimeric proteins were used for verifying their calcium-binding capabilities using various biophysical approaches. Following these findings, our lab further used subdomain approaches to verify the potential $\mathrm{Ca}^{2+}$-binding sites on the ECD, including the three previously identified $\mathrm{Ca}^{2+}$-binding sites and two additional $\mathrm{Ca}^{2+}$-binding sites: Site 2, which is composed of residues Glu215, Leu242, Ser244, Asp248, Gln253; and Site 4, which contains residues Glu350, Glu353, Glu354, Asn386, and Ser388. The three subdomains, comprising residues 132-300, 185-324, and 323-494 were expressed in a bacterial system. $\mathrm{Ca}^{2+}$-induced conformational changes were observed in spectroscopic studies using 8-anilino-1naphthalenesulfonic acid (ANS) fluorescence, intrinsic tryptophan spectra as well as nuclear magnetic resonance [69]. Moreover, the studies using subdomains of the CaSR also suggested multiple cooperative metal-binding processes as revealed by $\mathrm{Tb}^{3+}$ luminescence energy transfer studies and mutagenesis work on the putative $\mathrm{Ca}^{2+}$-binding sites [69]. More recently, using mutagenesis, we have shown that mutations in $\mathrm{Ca}^{2+}$-binding site 1 , such as Glu297 and Tyr218, not only disrupted the $\mathrm{Ca}^{2+}$-sensing capacity of the CaSR but also had an impact on the positive homotropic cooperative interactions of $\mathrm{Ca}^{2+}$ with other $\mathrm{Ca}^{2+}$-binding sites [70]. Moreover, molecular dynamic simulation results revealed that residues located at Site 1 showed strong correlated motions with other residues in the other four sites. These observations demonstrated the molecular connectivity among the five predicted $\mathrm{Ca}^{2+}$-binding sites with Site 1 playing a central role and have provided a description at the atomic level of the cross-talk between different $\mathrm{Ca}^{2+}$ binding sites of the CaSR.

The transmembrane domain of the CaSR (7TM) has been suggested to contain additional $\mathrm{Ca}^{2+}$-binding sites in a few studies [12,71]. Hauache et al. [12] engineered a chimeric receptor with the extracellular domain of rhodopsin linked with the transmembrane domain and intracellular C-tail of the CaSR to show that the chimeric receptor could be expressed at the cell surface and was able to response to extracellular $\mathrm{Ca}^{2+}$ in the presence of NPS R-568, a positive allosteric modulator of CaSR. Hu et al. [58] analyzed 12 naturally occurring activating mutations of the CaSR located in the 7TM domain and found that five of them were located at the junction of TM helices 6 and 7 between residues Ile819 and Glu837. They utilized alanine-scanning mutagenesis and revealed that Ile819-Glu837 played a key role in CaSR activation by $\mathrm{Ca}^{2+}$. The same group later found that substitution of three of the five acidic amino acids with alanine in the extracellular loop 2, Asp758, Glu759 and Glu767, increased the activity of the CaSR [71]. These findings indicated that $\mathrm{Ca}^{2+}$ could tune the receptor's function partially through the transmembrane domain.

\subsection{Amino acid-binding by the CaSR}

As a multimodal, multimetabolic sensor, the CaSR regulates whole body calcium homeostasis not only through its responses to extracellular $\mathrm{Ca}^{2+}$, but also by sensing L-amino acids [72]. Under physiological conditions, L-amino acids, especially aromatic amino acids (e.g., L-Phe), as well as short aliphatic and small polar amino acids [73], potentiate the high $\left[\mathrm{Ca}^{2+}\right]_{0}$-elicited activation of the CaSR by altering the $\mathrm{EC}_{50}$ values required for $\left[\mathrm{Ca}^{2+}\right]_{0}$-evoked $\left[\mathrm{Ca}^{2+}\right]_{\mathrm{i}}$ responses and its functional cooperativity [72,73]. The intracellular $\mathrm{Ca}^{2+}$ mobilization induced by $\mathrm{L}$-amino acids at the threshold level of extracellular $\mathrm{Ca}^{2+}$ concentration is characterized by slow oscillations with a frequency at around 1-2 peaks $\min ^{-1}$ [74]. Distinctive signaling pathways triggered by amino acids compared with extracellular $\mathrm{Ca}^{2+}$ have been confirmed in quite a few studies [74]. However, the specific binding pocket(s) for amino acids are still unclear due to the lack of structural information of the CaSR and the low binding affinity (in the $\mathrm{mmol} \mathrm{L}^{-1}$ range) of the ligands.

Sequence alignment of the CaSR with conserved amino acid residues that are involved in the binding of glutamate to mGluRs was applied as an initial approach to identify the potential L-Phe binding site [75]. Zhang et al. [75] demonstrated that mutating three adjacent Ser to Ala eliminated L-Phe potentiated receptor activity measured by cell population assay of changes in $\mathrm{Ca}^{2+}{ }_{i}$ using fluorimetry. In 2004 and 2005, Mun et al. [76] published two papers about L-amino acid-sensing in the CaSR. In their 2004 study, they confirmed the binding site for amino acids was within the VFT domain of the CaSR by utilizing CaSR-mGluR chimeric receptor constructs. The receptor lacking the CaSR ECD exhibited impaired response to L-amino acids. One year later, using mutagenesis and cell population studies, they showed that two residues, Thr145 and Ser170, could be crucial for sensing L-amino acids, since a double mutant of the CaSR, T145A/S170T, selectively failed to respond to L-Phe [77]. Recently, our lab reported an L-Phe binding site near the previously predicted calcium-binding Site 1 based on computational docking results and mutational studies using both single and cell population assays of receptor-induced changes in $\mathrm{Ca}^{2+}{ }_{i}[70]$. We found that the potential L-Phe-binding site is comprised of residues Leu51, Thr145, Ser170, Tyr218 and Ser272 and was responsible for positive heterotropic cooperativity between extracellular $\mathrm{Ca}^{2+}$ and L-Phe [70].

\subsection{The binding of allosteric modulators to the CaSR}

Distinct from L-amino acids, the allosteric modulators of the CaSR, many of which have a phenylalkylamine structure, have been proposed to regulate the CaSR's activity via interacting with its transmembrane domains instead of the extracellular domain $[71,78,79]$. Hauache et al. [12] made 
truncation and deletion mutants of the CaSR and engineered a chimeric protein with the ECD domain of the CaSR and the 7TM of mGluR1. Their results showed that the positive allosteric modulator of the CaSR, R-568, was effective in constructs with the 7TM from the CaSR but not in the ones with the mGluR1 7TM instead. Two years later, the same lab reported that an acidic residue, Glu837, in extracellular loop 3 was involved in the interaction with NPS R-568, as the CaSR mutant E837A abolished the NPS R-568potentiated receptor activity while maintaining partial $\mathrm{Ca}^{2+}$-sensing capability [71]. Two independent studies have used homology modeling of the 7TM domain of the CaSR based on the X-ray structure of rhodopsin to predict the potential binding site for the allosteric modulators. Miedlich et al. [79] found that mutations on residues Phe668, Arg680, Phe684 and Glu387 altered the CaSR's response to NPS2143, which is a negative allosteric modulator of the CaSR, suggesting their involvement in binding the drug. Petrel et al. [78] independently revealed that the binding pockets for calcimimetics and calcilytics were both located on the 7TM domain. They partially overlap with residues Trp818, Phe218, Glu837 and Il3841, but are not identical to the residues predicted in the other study. The recognition of calcilytics also involved residues in TM3 and TM5.

\subsection{Physiological relevance of studying ligand binding in vitro}

In biological systems, free L-amino acids are essential molecules since they not only serve as the building blocks of proteins but also are the metabolic precursors of crucial substances that serve as ligands for receptors [80]. Evidence for the presence of amino acid-sensing mechanisms in various studies, e.g., regulating insulin secretion from pancreatic $B$ cells, hepatic autophagy, etc., suggest the widespread existence of amino acid sensors, although the identities of these amino acid sensors are in many cases unknown. These findings highlight amino acid-dependent control of cellular signal transduction pathways. Fluctuation of the plasma levels of amino acids can, therefore, regulate the rate of hormone synthesis and secretion as well as $\mathrm{Ca}^{2+}$ metabolism, among other processes [80]. The CaSR is present throughout the gastrointestinal tract $[17,81]$, including in gastrin-secreting antral $\mathrm{G}$ cells and cholecystokinin-secreting 1 cells, both of which are known to be activated by both $\left[\mathrm{Ca}^{2+}\right]_{\mathrm{o}}$ and aromatic amino acids [81]. L-amino acids, especially aromatic amino acids, are known to enhance the sensitivity of the CaSR to $\left[\mathrm{Ca}^{2+}\right]_{\mathrm{o}}$, which could be one potential explanation for how dietary protein modulates $\left[\mathrm{Ca}^{2+}\right]_{\mathrm{o}}$ homeostasis in normal individuals as well as in patients with chronic renal failure [80,82].

The amino acid concentrations in plasma before and after a meal are listed in Table 1. All of them are within the $\mu \mathrm{mol}$ $\mathrm{L}^{-1}$ range. Even after a steak meal, the peak value for certain amino acids (e.g., Gly) is around $0.5 \mathrm{mmol} \mathrm{L}^{-1}$ [83]. However, the reported $\mathrm{EC}_{50}$ for activation of the CaSR by L-Phe was $3.5 \mathrm{mmol} \mathrm{L}^{-1}$ as measured by intracellular calcium readout from the CaSR-transfected HEK293 cells [73]. The discrepancy for these phenomena relies on the fact that in physiological conditions, the receptors are stimulated by a mixture of amino acids, small peptides as well as proteins instead of a single amino acid. In fact, small peptides, for instance, $\gamma$-glutathione and its variants, have lower $\mathrm{EC}_{50} \mathrm{~s}$ (in the range of $\mu \mathrm{mol} \mathrm{L}{ }^{-1}$ ) compared with L-Phe or L-Trp (Table 2).

Conigrave et al. [73] have investigated the physiological relevance of their in vitro findings regarding the amino acid concentration dependence of the CaSR. They mixed 20 common L-amino acids at similar concentration compared to those present in fasting human plasma and showed that the mixture could reproduce the effects of high concentrations of single amino acids. These findings suggest that the CaSR sensing L-amino acid is a universal property and the amino acid composition of human plasma has a pronounced effect on the activity of the CaSR compared to single amino acids.

The metabolism of both $\mathrm{Ca}^{2+}$ and amino acids will be re-appraised in the context of protein ingestion and dietary supplements, since L-amino acid and $\mathrm{Ca}^{2+}$ can potentiate the sensing capability by the CaSR for each other. It was also emphasized by Conigrave et al. [73] that the CaSR should

Table 1 Plasma amino acid concentrations before and during intravenous amino acid infusion and after an oral steak meal $\left(\mu \mathrm{mol} \mathrm{L}^{-1}\right)$

\begin{tabular}{|c|c|c|c|c|c|c|}
\hline Amino acid infused IV & Basal & $0-60 \mathrm{~min}$ & $61-120 \mathrm{~min}$ & $121-180 \mathrm{~min}$ & $181-240 \mathrm{~min}$ & Steak meal \\
\hline Phe & $51 \pm 5$ & $68 \pm 8$ & $90 \pm 7^{*}$ & $103 \pm 14^{*}$ & $198 \pm 37^{*}$ & $85 \pm 7$ \\
\hline $\operatorname{Trp}$ & $49 \pm 5$ & $66 \pm 6$ & $97 \pm 8^{*}$ & $140 \pm 16^{*}$ & $244 \pm 38^{*}$ & $94 \pm 9$ \\
\hline Ala & $316 \pm 16$ & $345 \pm 15$ & $353 \pm 25$ & $326 \pm 10$ & $365 \pm 31$ & $549 \pm 50$ \\
\hline His & $80 \pm 14$ & $104 \pm 8$ & $130 \pm 10$ & $172 \pm 19$ & $316 \pm 25$ & $100 \pm 11$ \\
\hline
\end{tabular}

a) *, Time period when gastric acid secretion was significantly greater than saline control. Mean ( \pm SE) plasma amino acid concentrations of phenylalanine, tryptophan, glycine, alanine, and histidine before (basal) and in response to intravenous infusion of each individual amino acid and after the steak meal. Each amino acid was infused in $125 \mathrm{~mL}$ for $1 \mathrm{~h}$ in increasing stepwise manner; doses of Phe, Gly, Ala, and His were $0.0125,0.025,0.05$, and $0.1 \mathrm{~mol} \mathrm{~L}^{-1}$, respectively, and doses of Trp were $0.005,0.01,0.02$, and $0.04 \mathrm{~mol} \mathrm{~L}^{-1}$. The steak meal contained $49 \mathrm{~g}$ protein and $405 \mathrm{kcal}$ (table adopted from [83]). 
Table 2 Potencies of $\gamma$-glutamyl peptides for $\left[\mathrm{Ca}^{2+}\right]_{\mathrm{i}}$ mobilization in CaSR-expressing HEK-293 cells

\begin{tabular}{cc}
\hline$\gamma$-Glutamyl peptide & $\mathrm{EC}_{50}$ for peptide $\left(\mu \mathrm{mol} \mathrm{L}{ }^{-1}\right)$ \\
\hline$S$-Methylglutathione & $1.7 \pm 0.5(n=4)$ \\
Glutathione & $3.9 \pm 0.7(n=4)$ \\
$\gamma$-Glu-Cys & $4.7 \pm 0.9(n=3)$ \\
$\gamma$-Glu-Ala & $4.8 \pm 0.7(n=3)$ \\
\hline
\end{tabular}

a) HEK-293 cells that stably express the CaSR were loaded with fura-2AM and assayed for receptor-dependent intracellular $\mathrm{Ca}^{2+}$ mobilization by microfluorimetry. The data were obtained from cells perfused with physiological saline solution in the presence of $2.5 \mathrm{mmol} \mathrm{L}^{-1}\left[\mathrm{Ca}^{2+}\right]_{\mathrm{o}}$. In the accompanying experiments, the $\mathrm{EC}_{50}$ for L-Phe was $1.1 \pm 0.5 \mathrm{mmol} \mathrm{L}{ }^{-1}$ $(n=4)$ (table adopted from [84]

be reassessed as a potential target of aromatic L-amino acids under certain toxic metabolic conditions. For instance, the CaSR expressed in the CNS might be involved in contributing to the toxic effects resulting from the elevated levels of L-Phe in phenylketonuria or in hepatic encephalopathy.

\section{Proteins interacting with the CaSR}

In addition to heterotrimeric $\mathrm{G}$ proteins, the CaSR needs to recruit a number of other proteins to ensure that signaling networks are fully functional. Recently, a few of these proteins have been identified using the yeast two-hybrid system and/or co-immunoprecipitation studies. The absence of these proteins would, in turn, influence the CaSR signaling.

Filamin A has been demonstrated to interact with the C-terminal of the CaSR in 2001 by two individual groups $[61,62]$. Later studies using truncation and deletion mutants revealed that the binding took place in a two $\beta$-strands region from amino acid 962 to 981 of the CaSR. Blocking the interaction between Filamin A and the CaSR attenuated CaSR-induced ERK activity [61]. The binding of the two proteins also exhibited importance in CaSR-mediated Rho signaling [85,86] as well as JNK activation [87]. Studies in a cell line deficient in Filamin A suggested that Filamin A might protect the CaSR from degradation [88].

Potassium channels (Kir4.2 and Kir4.1) have been reported to colocalize with the CaSR in HEK293 cells stably expressing the CaSR as well as in endogenous rat kidney tissues [89]. However, how and whether their function can be regulated by the CaSR still needs to be elucidated. It is possible that Filamin A may act as a bridge that links the CaSR with either Kir4.1 or Kir4.2.

The region between amino acids 880-900 of the CaSR has been identified to interact with the region $660-838$ of an E3 ubiquitin ligase, dorfin [90]. Overexpression of dorfin is believed to increase the ubiquitination of the CaSR, resulting in accelerated degradation [90].

Associated molecule with SH3 domain of STAM (AMSH) is an ubiquitin isopeptidase that regulates the sorting of the receptor EGFR [91]. The CaSR C-tail region from 895-1075 was found to bind to AMSH [92]. Increasing AMSH expression level or stimulating the CaSR with calcium could reduce CaSR expression in HEK293 cells transfected with these two proteins $[92,93]$.

$\beta$-arrestins play an important role in modulating the desensitization and internalization of GPCRs through collaborating with $G$ protein receptor kinases (GRK) [94]. Overexpression of $\beta$-arrestins negatively regulates the inositol phosphate signaling mediated by the CaSR in HEK293 cells. A PKC inhibitor or mutation of the CaSR PKC phosphorylation sites reduces the effect of overexpressing $\beta$-arrestins.

RAMP is an abbreviation for receptor activity-modifying protein, which has been reported to influence receptor trafficking, glycosylation as well as second messenger production [95]. Experiments in COS7 cells demonstrated that RAMP1 and RAMP3, but not RAMP2, can increase the surface expression of the co-transfected CaSR [96]. Moreover, RAMP3 had a greater influence on modulating the cell surface expression of the receptor.

\section{Trafficking of the CaSR in cells}

Like many other GPCRs, the trafficking of the CaSR is a complex process that involves interacting with various proteins that determine the final destination of the receptor. Once synthesized in the endoplasmic reticulum (ER), CaSR that is improperly folded will fail the quality control process and be shunted toward the proteasome for degradation. Receptors passing the quality control process will traffic to the plasma membrane or other cellular compartments via interaction with chaperones and small GTP-binding proteins [97-100].

Several proteins interact with the CaSR when the receptor exits from the ER, including p24A (transmembrane emp24 domain trafficking protein 2(TMED2)) [101]; the small GTP-binding protein Sar1 [102]; receptor-activitymodifying proteins (RAMPs) [96]; Rab1 [103]; calmodulin (CaM) [63]; 14-3-3 [104] and Dorfin [90]. p24A binds predominantly to the immature form of the CaSR and cycles between the ER, the ER-Golgi intermediate compartment (ERGIC) and the cis-Golgi membranes [105,106]. Through its interaction with p24A, the stability of the CaSR and its plasma membrane targeting will be increased, possibly via an increase in total receptor number [101]. Sar1 is another protein that is required for releasing the receptor from the ER [101,102]. RAMPs and Rab1 are small GTP-binding proteins that localize to the cytoplasmic face of organelle membranes. Both of them are found to facilitate the CaSR trafficking from ER to Golgi [96,103]. The 14-3-3 protein is predicted to interact with the arginine-rich domain of the CaSR $\left({ }^{890} \mathrm{RRxxxxRKR}{ }^{898}\right)$ and may lead to the retention of the CaSR in the ER $[65,104,107]$. There is also a calmodulin-binding site in the $\mathrm{C}$-tail of the CaSR comprising residues 874-895 [47]. However, the function of CaM still 
needs to be revealed. It is reported that CaM binds to both immature and mature forms of the CaSR, suggesting its role in modulating anterograde trafficking of the receptor [63]. On the other hand, CaM may stabilize the surface receptor on the cell membrane [47].

Its interactions with several different proteins contribute to the subcellular localization of the CaSR. The association of intracellular loops 1 and 3 with caveolins keeps the CaSR highly enriched in invaginations of plasma membrane called caveolae in certain types of cells, like parathyroid chief cells and cardiac myocytes [19,108-110]. Filamin A, a scaffold/adaptor protein, has also been shown to interact with the C-terminal of the CaSR, targeting the receptor to sites of Rho activity [85,86,111]. The CaSR also interacts with integrins, and the latter may contribute to the regulation of cell migration [7].

The surface expressed CaSR may undergo endocytosis initiated by phosphorylation by $\mathrm{G}$ protein-coupled receptor kinases (GRKs) or protein kinase C [112,113], involving $\beta$-arrestins and facilitated by Rab7, Rab11a and adaptor protein-2 (AP2) [93,114,115]. The endocytosed receptors are either recycled to the cell membrane, thereby contributing to the receptor resensitization, or translocated to lysosomes for degradation [116,117].

There are two mechanisms involved in degradation of the CaSR. One is mediated by the activity of the E3 ubiquitin ligase family member, dorfin. The CaSR will be targeted to the proteasome after being ubiquitinated by dorfin [118]. The CaSR can also be degraded in lysosomes. A deubiquitinating enzyme specific for k63-linkages (AMSH, which is short for associated molecule with the SH3 domain of STAM) has been reported to be involved in this process [93]. Moreover, the PEST-like sequence in the C-tail of the $\mathrm{CaSR}$, which is rich in proline, glutamine, serine and threonine, can also lead the receptor to lysosomes [115].

In the continuous presence of agonist stimulation, those secretory pathways as well as the endocytosis mechanisms mentioned above work collaboratively, causing a net increase in CaSR expressed on the plasma membrane. This phenomenon was named Agonist-Driven Insertional Signaling (ADIS) [104]. However, a number of questions raised by the ADIS mechanism remained to be explored.

\section{The disease-associated CaSR mutations}

The discovery of the CaSR and its role in maintaining physiological calcium level led to the identification of disorders of calcium homeostasis that are related to abnormal receptor activity. There are more than 200 mutations of the CaSR that have been catalogued in the online database at http://www.casrdb.mcgill.ca/. The CaSRdb is the primary attribution for the CaSR-related disorders [119]. Autoimmune antibodies against the CaSR are another cause for receptor dysfunction [120-122].
Mutations of the CaSR may lead to an inactive receptor or an overactive receptor. The majority of these disease-associated mutations are missense mutations, with single amino acid substituted. Amino acids insertion, deletion, open reading frame shift and splice-site mutations have also been reported [119].

The disorders associated with inactive receptors include cases of familial hypocalciuric hypercalcemia (FHH), which in more severe cases can be associated with dominant negative activity of the mutant CaSR [123] as well as a more serious disorder known as neonatal severe hyperparathyroidism (NSHPT), most commonly due to inactivating mutations in both copies of the CaSR gene [120]. Mild to moderate hypercalcemia (no more than $20 \%$ above the upper limit of normal of the serum calcium level) and unusually high renal tubular reabsorption of calcium are the key clinical features of FHH [119]. On the other hand, NSHPT is a rare disorder characterized by marked symptomatic hypercalcemia and usually occurs in children younger than 6 months. NSHPT can cause multiple fractures, neurodevelopmental disorders and even death.

The disorders associated with the CaSR activating mutations include autosomal dominant hypocalcemia (ADH) [124] and Bartter syndrome type V [125]. Patients with ADH usually do not show symptoms but have mild reductions in calcium concentration in the blood. Seizures may happen to younger patients, often occurring during febrile episodes. Serum PTH levels are generally within or near the lower limit of the normal range. Calcium concentration in the urine is higher than in hypoparathyroid patients of other etiologies. Bartter's syndrome subtype V is associated with severe heterozygous activating mutations in the CaSR. Patients with Bartter syndrome type $\mathrm{V}$ show symptoms like hypokalemic metabolic alkalosis and hyperaldosteronism along with hypocalcemia [125].

Hannan et al. [126] have reported that the majority $(>50 \%)$ of their newly identified CaSR mutations in patients with FHH, NSHPT and autosomal dominant hypocalcemic hypercalciuria are missense substitutions within the ECD of the CaSR. Combining their study with previously reported disease-associated the CaSR mutations, here we show that the bilobed VFTD plays a pivotal role in interacting with $\mathrm{Ca}^{2+}$ and regulating the function of the CaSR, as more than half of the mutations occurred in the ECD (Figure 3C). By analyzing the homology modeled structure of the CaSR, our studies further revealed that $>50 \%$ of these mutations are situated within $10 \AA$ of one or more calcium-binding sites [126]. Moreover, since a substantial percentage $(>50 \%)$ of the mutations near calcium-binding sites are located at Site 1 , the importance of VFTD cleft is highlighted. The rest of the calcium-binding sites can possibly play an auxiliary role by building molecular connectivity between Site 1 as well as other calcium-binding sites and thereby enhancing positive cooperativity [70].

Recently, studies have appeared showing that disorders 


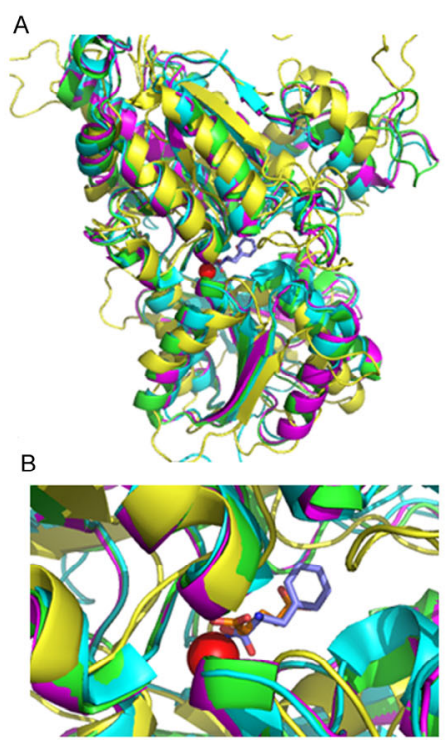

C

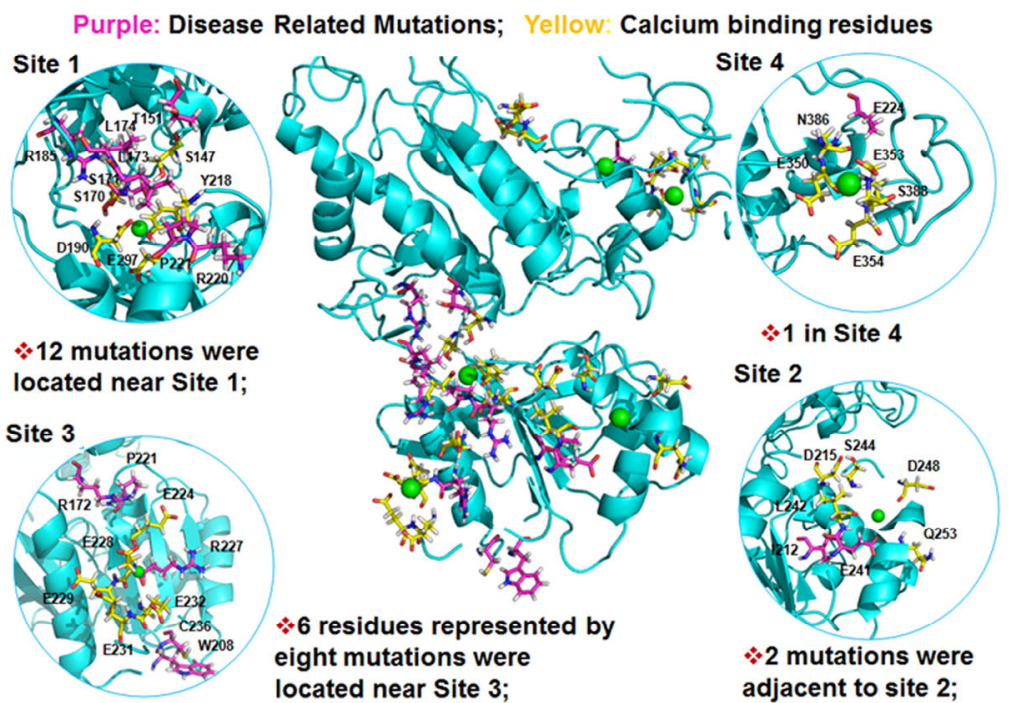

Figure 3 Mapping the disease-associated mutations on the modeled CaSR ECD. A, Overlay of modeled structure of Ca ${ }^{2+}$-sensing receptor with crystal structures of mGluR1, mGluR3 and mGluR5. The modeled CaSR extracellular domain (ECD), highlighted in yellow, is based on mGluR1 (pdb: 1EWK). mGluR1 (pdb:1EWK) is highlighted in green, mGluR3 (pdb:2E4U) is highlighted in cyan, mGluR5 (pdb:3LMK) is highlighted in violet. Calcium is labeled in red, L-Phe is in purple [68]. B, The zoom in view of the hinge region. Purple: L-Phe; orange: glutamate. C, Disease-related CaSR mutations on ECD. Cyan: the modeled structure of the CaSR ECD; purple: residues involved in disease-associated mutations reported in the recent studies by Hannan et al.; yellow: residues involved in predicted calcium binding pockets.

with an FHH or ADH phenotype may not directly involve mutations of the CaSR, but can be associated with mutations of other proteins that participate in CaSR-mediated signaling [114,127]. Familial hypocalciuric hypercalcemia type 2 (FHH2) and familial hypocalciuric hypercalcemia type 3 (FHH3) are genetically distinct, autosomal dominant disorders of extracellular calcium homeostasis in the absence of mutations in the CaSR. The first form of FHH identified, caused by mutations of the CaSR gene on chromosome $3 \mathrm{q} 21.1$, is now called familial hypocalciuric hypercalcemia type 1 (FHH1). The loci for FHH2 and FHH3, in contrast, are located on chromosomes $19 p$ and $19 q 13.3$ respectively [114]. Loss-of-function mutations of G-protein subunit- $\alpha 11$ (GNA11) cause FHH2, and loss-of-gain mutations of the sigma subunit of adaptor protein-2 (AP2), a central component of clathrin-coated vesicles (CCVs), decrease the sensitivity of CaSR to extracellular calcium changes, in association with reduced CaSR endocytosis, and lead to FHH3 [114,127]. Conversely, in addition to the first form of $\mathrm{ADH}$ identified, now called ADH type 1, which is due to activating mutations of the CaSR as noted above, ADH type 2 is caused by gain-of-function mutations of G-protein subunit- $\alpha 11$ (GNA11). Gain-of-function mutations of adaptor protein-2 sigma subunit (AP2 $\sigma 2)$ represent a theoretically possible cause of $\mathrm{ADH}$, but have not been identified as of yet [127].

\section{Conclusion and future perspectives}

Throughout this review, the molecular characteristics that contribute to the structural biology of the CaSR in $\left[\mathrm{Ca}^{2+}\right]_{0}$-sensing and $\mathrm{Ca}^{2+}$ signaling have been summarized. On the way to providing advanced information about the structural features related with this receptor as well as other proteins in GPCR family $\mathrm{C}$, researchers will continue to face several challenges.

First, the CaSR is a membrane protein, so the challenges associated with studying membrane proteins may also occur with the CaSR. Membrane proteins are difficult to separate from the cells due to their hydrophobic transmembrane domains. Secondly, although X-ray crystallography has been used as one of the major tools to study the structure of proteins, application of this technique to the crystallization of glycosylated proteins exhibits its own limitations. Like other glycosylated proteins, the complex form of the glycans on the CaSR can prevent crystallization of this protein because the chemical and conformational heterogeneity of the glycoproteins usually inhibit crystallization. Thirdly, due to the limitation of the conditions for crystallization as well as the fast on and off rate of $\mathrm{Ca}^{2+}$ when its interaction belongs to weak binding, even in some proteins that have had their crystal structure solved like mGluR1, the detection of $\mathrm{Ca}^{2+}$-binding sites in those proteins may be still elusive. Moreover, the selectivity of the CaSR for different amino acids is not clear and the interaction between amino acids and the CaSR are relatively weak (in mmol $\mathrm{L}^{-1}$ range). Fourthly, currently, methods for direct measurement of $\mathrm{Ca}^{2+}$ and amino acid binding to the CaSR have not yet been well established, nor are there methods for directly monitoring ligand induced conformational changes of the proteins. Ap- 


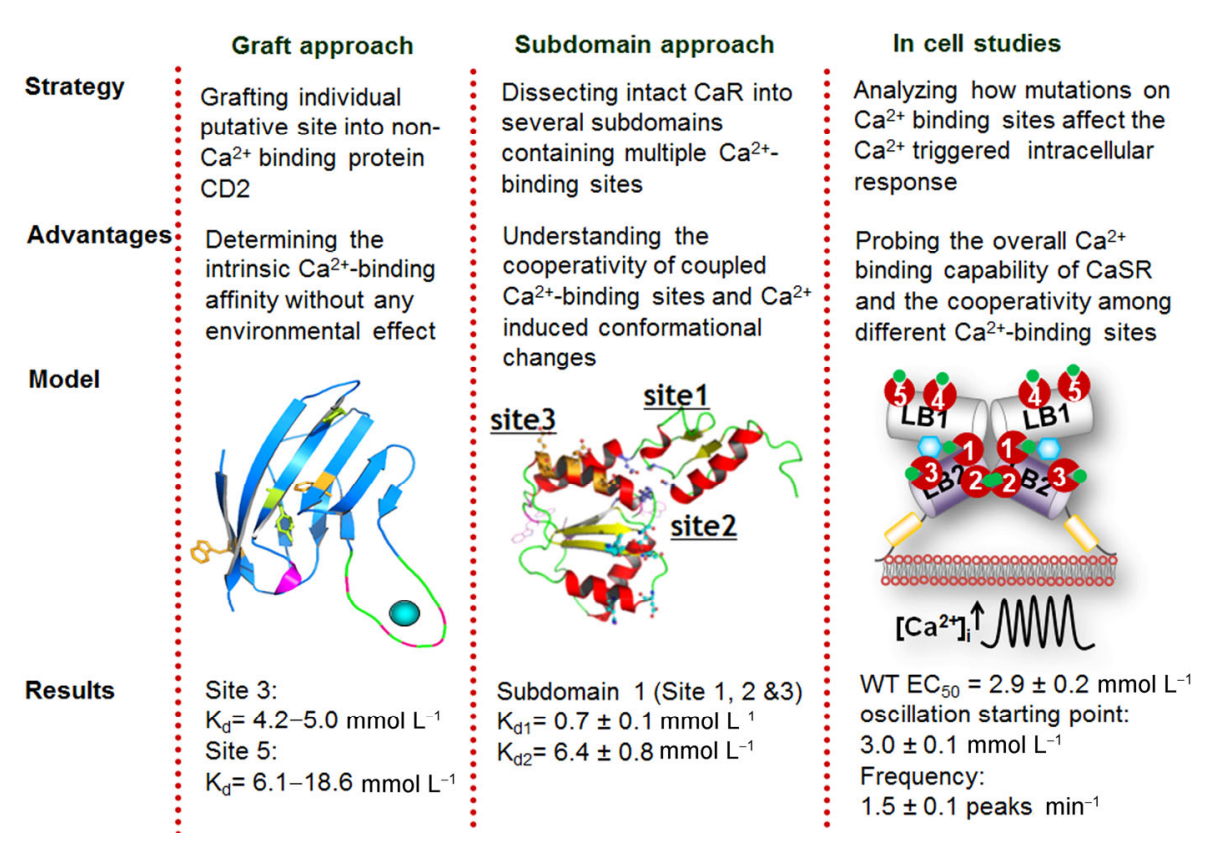

Figure 4 Summary of research approaches.

proaches for addressing these questions rely on indirect measurements of calcium-induced intracellular signaling changes in living cells or utilizing the fluorescence resonance energy transfer (FRET) assay for monitoring ligand-generated fluorescence changes in isolated proteins. Last but not least, the large size of the protein (extracellular domain 612 amino acids; whole protein 1078 amino acids) as well as the fact that the CaSR functions as a dimer contribute to the difficulties in studying the protein, especially when it possesses a high Hill coefficient which suggests possible multiple binding sites for ligands.

However, these challenges can be overcome by innovative experimental designs and advanced technologies. In our lab, we have utilized a grafting approach, subdomain approach and intact cell studies to probe the potential calcium-binding sites on the extracellular domain of CaSR and the functional cooperativity among them (Figure 4). Amino acid-selective isotopic labeling of proteins will be applicable to structural studies of proteins that are not amenable to traditional NMR studies [128]. Various $\mathrm{Ca}^{2+}$ sensors can be employed to monitor intracellular calcium signaling and further understand how different allosteric modulators as well as drugs for the CaSR regulate the receptor function. A better understanding of the molecular properties of the CaSR using cutting edge technologies is in demand to provide greater therapeutic approaches since the receptor is involved in various physiological functions.

Work in the Dr. Jenny Yang's laboratory was supported by the US National Institutes of Health (GM081749 and EB007268); a Center for Diagnostics and Therapeutics fellowship (to Zhang Chen), and funds from the Georgia Research Alliance.
1 Ringer S. A further contribution regarding the influence of the different constituents of the blood on the contraction of the heart. J Physiol, 1883, 4: 29-42

2 Krebs J, Michalak M, eds. Calcium: a matter of life or death. Elsevier, 2007

3 Smajilovic S, Tfelt-Hansen J. Calcium acts as a first messenger through the calcium-sensing receptor in the cardiovascular system. Cardiovasc Res, 2007, 75: 457-467

4 Koleganova N, Piecha G, Ritz E, Schmitt CP, Gross ML. A calcimimetic (R-568), but not calcitriol, prevents vascular remodeling in uremia. Kidney Int, 2009, 75: 60-71

5 Liao J, Schneider A, Datta NS, McCauley LK. Extracellular calcium as a candidate mediator of prostate cancer skeletal metastasis. Cancer Res, 2006, 66: 9065-9073

6 Ogata H, Ritz E, Odoni G, Amann K, Orth SR. Beneficial effects of calcimimetics on progression of renal failure and cardiovascular risk factors. J Am Soc Nephrol, 2003, 14: 959-967

7 Tharmalingam S, Daulat AM, Antflick JE, Ahmed SM, Nemeth EF, Angers S, Conigrave AD, Hampson DR. Calcium-sensing receptor modulates cell adhesion and migration via integrins. J Biol Chem, 2011, 286: 40922-40933

8 Francesconi A, Duvoisin RM. Divalent cations modulate the activity of metabotropic glutamate receptors. J Neurosci Res, 2004, 75: $472-479$

9 Spilker C, Dresbach T, Braunewell KH. Reversible translocation and activity-dependent localization of the calcium-myristoyl switch protein VILIP-1 to different membrane compartments in living hippocampal neurons. J Neurosci, 2002, 22: 7331-7339

10 Zonta M, Sebelin A, Gobbo S, Fellin T, Pozzan T, Carmignoto G. Glutamate-mediated cytosolic calcium oscillations regulate a pulsatile prostaglandin release from cultured rat astrocytes. J Physiol, 2003, 553: 407-414

11 Wise A, Green A, Main MJ, Wilson R, Fraser N, Marshall FH. Calcium sensing properties of the GABA(B) receptor. Neuropharmacology, 1999, 38: 1647-1656

12 Hauache OM, Hu J, Ray K, Xie R, Jacobson KA, Spiegel AM. Effects of a calcimimetic compound and naturally activating mutations on the human $\mathrm{Ca}^{2+}$ receptor and on $\mathrm{Ca}^{2+}$ receptor/metabotropic glutamate chimeric receptors. Endocrinology, 2000, 141: 4156-4163 
13 Parekh AB. Decoding cytosolic $\mathrm{Ca}^{2+}$ oscillations. Trends Biochem Sci, 2011, 36: 78-87

14 Brown EM, Gamba G, Riccardi D, Lombardi M, Butters R, Kifor O, Sun A, Hediger MA, Lytton J, Hebert SC. Cloning and characterization of an extracellular $\mathrm{Ca}(2+)$-sensing receptor from bovine parathyroid. Nature, 1993, 366: 575-580

15 Muff R, Nemeth EF, Haller-Brem S, Fischer JA. Regulation of hormone secretion and cytosolic $\mathrm{Ca}^{2+}$ by extracellular $\mathrm{Ca}^{2+}$ in parathyroid cells and C-cells: role of voltage-sensitive $\mathrm{Ca}^{2+}$ channels. Arch Biochem Biophys, 1988, 265: 128-135

16 Nemeth EF, Scarpa A. Rapid mobilization of cellular $\mathrm{Ca}^{2+}$ in bovine parathyroid cells evoked by extracellular divalent cations. Evidence for a cell surface calcium receptor. J Biol Chem, 1987, 262: 5188-5196

17 Brown EM, MacLeod RJ. Extracellular calcium sensing and extracellular calcium signaling. Physiol Rev, 2001, 81: 239-297

18 Brown EM. The extracellular $\mathrm{Ca}^{2+}$-sensing receptor: central mediator of systemic calcium homeostasis. Annu Rev Nutr, 2000, 20: 507-533

19 Kifor O, Diaz R, Butters R, Kifor I, Brown EM. The calcium-sensing receptor is localized in caveolin-rich plasma membrane domains of bovine parathyroid cells. J Biol Chem, 1998, 273: 21708-21713

20 Riccardi D, Park J, Lee WS, Gamba G, Brown EM, Hebert SC. Cloning and functional expression of a rat kidney extracellular calcium/polyvalent cation-sensing receptor. Proc Natl Acad Sci USA, 1995, 92: 131-135

21 Butters RR Jr., Chattopadhyay N, Nielsen P, Smith CP, Mithal A, Kifor O, Bai M, Quinn S, Goldsmith P, Hurwitz S, Krapcho K, Busby J, Brown EM. Cloning and characterization of a calcium-sensing receptor from the hypercalcemic New Zealand white rabbit reveals unaltered responsiveness to extracellular calcium. J Bone Miner Res, 1997, 12: 568-579

22 Riccardi D, Hall AE, Chattopadhyay N, Xu JZ, Brown EM, Hebert SC. Localization of the extracellular $\mathrm{Ca}^{2+} /$ polyvalent cation-sensing protein in rat kidney. Am J Physiol, 1998, 274: F611-622

23 Chattopadhyay N, Cheng I, Rogers K, Riccardi D, Hall A, Diaz R, Hebert SC, Soybel DI, Brown EM. Identification and localization of extracellular $\mathrm{Ca}(2+)$-sensing receptor in rat intestine. Am J Physiol, 1998, 274: G122-130

24 Cima RR, Cheng I, Klingensmith ME, Chattopadhyay N, Kifor O, Hebert SC, Brown EM, Soybel DI. Identification and functional assay of an extracellular calcium-sensing receptor in Necturus gastric mucosa. Am J Physiol, 1997, 273: G1051-1060

25 Buchan AM, Squires PE, Ring M, Meloche RM. Mechanism of action of the calcium-sensing receptor in human antral gastrin cells. Gastroenterology, 2001, 120: 1128-1139

26 Busque SM, Kerstetter JE, Geibel JP, Insogna K. L-type amino acids stimulate gastric acid secretion by activation of the calcium-sensing receptor in parietal cells. Am J Physiol Gastrointest Liver Physiol, 2005, 289: G664-669

27 Justinich CJ, Mak N, Pacheco I, Mulder D, Wells RW, Blennerhassett MG, MacLeod RJ. The extracellular calcium-sensing receptor (CaSR) on human esophagus and evidence of expression of the CaSR on the esophageal epithelial cell line (HET-1A). Am J Physiol Gastrointest Liver Physiol, 2008, 294: G120-129

28 Chakrabarty S, Radjendirane V, Appelman H, Varani J. Extracellular calcium and calcium sensing receptor function in human colon carcinomas: promotion of E-cadherin expression and suppression of beta-catenin/TCF activation. Cancer Res, 2003, 63: 67-71

29 Kallay E, Kifor O, Chattopadhyay N, Brown EM, Bischof MG, Peterlik M, Cross HS. Calcium-dependent c-myc proto-oncogene expression and proliferation of Caco-2 cells: a role for a luminal extracellular calcium-sensing receptor. Biochem Biophys Res Commun, 1997, 232: 80-83

30 Yamaguchi T, Chattopadhyay N, Kifor O, Butters RR Jr., Sugimoto T, Brown EM. Mouse osteoblastic cell line (MC3T3-E1) expresses extracellular calcium $\left(\mathrm{Ca}^{2+} \mathrm{o}\right)$-sensing receptor and its agonists stimu- late chemotaxis and proliferation of MC3T3-E1 cells. J Bone Miner Res, 1998, 13: 1530-1538

31 Chattopadhyay N, Yano S, Tfelt-Hansen J, Rooney P, Kanuparthi D, Bandyopadhyay S, Ren X, Terwilliger E, Brown EM. Mitogenic action of calcium-sensing receptor on rat calvarial osteoblasts. Endocrinology, 2004, 145: 3451-3462

32 Dvorak MM, Siddiqua A, Ward DT, Carter DH, Dallas SL, Nemeth EF, Riccardi D. Physiological changes in extracellular calcium concentration directly control osteoblast function in the absence of calciotropic hormones. Proc Natl Acad Sci USA, 2004, 101: 5140-5145

33 Mentaverri R, Yano S, Chattopadhyay N, Petit L, Kifor O, Kamel S, Terwilliger EF, Brazier M, Brown EM. The calcium sensing receptor is directly involved in both osteoclast differentiation and apoptosis. FASEB J, 2006, 20: 2562-2564

34 Kameda T, Mano H, Yamada Y, Takai H, Amizuka N, Kobori M, Izumi N, Kawashima H, Ozawa H, Ikeda K, Kameda A, Hakeda Y, Kumegawa M. Calcium-sensing receptor in mature osteoclasts, which are bone resorbing cells. Biochem Biophys Res Commun, 1998, 245: 419-422

35 Yano S, Brown EM, Chattopadhyay N. Calcium-sensing receptor in the brain. Cell Calcium, 2004, 35: 257-264

36 Chang W, Tu C, Cheng Z, Rodriguez L, Chen TH, Gassmann M, Bettler B, Margeta M, Jan LY, Shoback D. Complex formation with the Type B gamma-aminobutyric acid receptor affects the expression and signal transduction of the extracellular calcium-sensing receptor. Studies with HEK-293 cells and neurons. J Biol Chem, 2007, 282: 25030-25040

37 Gama L, Wilt SG, Breitwieser GE. Heterodimerization of calcium sensing receptors with metabotropic glutamate receptors in neurons. J Biol Chem, 2001, 276: 39053-39059

38 Washburn DL, Anderson JW, Ferguson AV. A subthreshold persistent sodium current mediates bursting in rat subfornical organ neurones. J Physiol, 2000, 529(Pt 2): 359-371

39 Vassilev PM, Ho-Pao CL, Kanazirska MP, Ye C, Hong K, Seidman CE, Seidman JG, Brown EM. Cao-sensing receptor (CaR)-mediated activation of $\mathrm{K}^{+}$channels is blunted in CaR gene-deficient mouse neurons. Neuroreport, 1997, 8: 1411-1416

40 Ye C, Ho-Pao CL, Kanazirska M, Quinn S, Seidman CE, Seidman JG, Brown EM, Vassilev PM. Deficient cation channel regulation in neurons from mice with targeted disruption of the extracellular $\mathrm{Ca}^{2+}$-sensing receptor gene. Brain Res Bull, 1997, 44: 75-84

41 Wang R, Xu C, Zhao W, Zhang J, Cao K, Yang B, Wu L. Calcium and polyamine regulated calcium-sensing receptors in cardiac tissues. Eur J Biochem, 2003, 270: 2680-2688

42 Wang LN, Wang C, Lin Y, Xi YH, Zhang WH, Zhao YJ, Li HZ, Tian Y, Lv YJ, Yang BF, Xu CQ. Involvement of calcium-sensing receptor in cardiac hypertrophy-induced by angiotensinII through calcineurin pathway in cultured neonatal rat cardiomyocytes. Biochem Biophys Res Commun, 2008, 369: 584-589

43 Lu F, Tian Z, Zhang W, Zhao Y, Bai S, Ren H, Chen H, Yu X, Wang J, Wang L, Li H, Pan Z, Tian Y, Yang B, Wang R, Xu C. Calcium-sensing receptors induce apoptosis in rat cardiomyocytes via the endo(sarco)plasmic reticulum pathway during hypoxia/reoxygenation. Basic Clin Pharmacol Toxicol, 2010, 106: 396-405

44 Bai M, Quinn S, Trivedi S, Kifor O, Pearce SH, Pollak MR, Krapcho $\mathrm{K}$, Hebert SC, Brown EM. Expression and characterization of inactivating and activating mutations in the human $\mathrm{Ca}^{2+} \mathrm{O}$-sensing receptor. J Biol Chem, 1996, 271: 19537-19545

45 Ray K, Clapp P, Goldsmith PK, Spiegel AM. Identification of the sites of N-linked glycosylation on the human calcium receptor and assessment of their role in cell surface expression and signal transduction. J Biol Chem, 1998, 273: 34558-34567

46 Bai M, Trivedi S, Brown EM. Dimerization of the extracellular calcium-sensing receptor $(\mathrm{CaR})$ on the cell surface of CaR-transfected HEK293 cells. J Biol Chem, 1998, 273: 23605-23610

47 Huang Y, Zhou Y, Wong HC, Castiblanco A, Chen Y, Brown EM, 
Yang JJ. Calmodulin regulates $\mathrm{Ca}^{2+}$-sensing receptor-mediated $\mathrm{Ca}^{2+}$ signaling and its cell surface expression. J Biol Chem, 2010, 285: 35919-35931

48 Hofer AM, Brown EM. Extracellular calcium sensing and signalling. Nat Rev Mol Cell Biol, 2003, 4: 530-538

49 Ward DT. Calcium receptor-mediated intracellular signalling. Cell Calcium, 2004, 35: 217-228

$50 \mathrm{Hu} \mathrm{J}$, Spiegel AM. Structure and function of the human calcium-sensing receptor: insights from natural and engineered mutations and allosteric modulators. J Cell Mol Med, 2007, 11: 908-922

51 Ray K, Hauschild BC, Steinbach PJ, Goldsmith PK, Hauache O, Spiegel AM. Identification of the cysteine residues in the amino-terminal extracellular domain of the human $\mathrm{Ca}(2+)$ receptor critical for dimerization. Implications for function of monomeric $\mathrm{Ca}(2+)$ receptor. J Biol Chem, 1999, 274: 27642-27650

52 Reyes-Cruz G, Hu J, Goldsmith PK, Steinbach PJ, Spiegel AM. Human $\mathrm{Ca}(2+)$ receptor extracellular domain. Analysis of function of lobe I loop deletion mutants. J Biol Chem, 2001, 276: 32145-32151

53 Pace AJ, Gama L, Breitwieser GE. Dimerization of the calcium-sensing receptor occurs within the extracellular domain and is eliminated by Cys --> Ser mutations at Cys101 and Cys236. J Biol Chem, 1999, 274: 11629-11634

54 Zhang Z, Sun S, Quinn SJ, Brown EM, Bai M. The extracellular calcium-sensing receptor dimerizes through multiple types of intermolecular interactions. J Biol Chem, 2001, 276: 5316-5322

55 Fan GF, Ray K, Zhao XM, Goldsmith PK, Spiegel AM. Mutational analysis of the cysteines in the extracellular domain of the human $\mathrm{Ca}^{2+}$ receptor: effects on cell surface expression, dimerization and signal transduction. FEBS Lett, 1998, 436: 353-356

$56 \mathrm{Hu}$ J, Hauache O, Spiegel AM. Human $\mathrm{Ca}^{2+}$ receptor cysteine-rich domain. Analysis of function of mutant and chimeric receptors. J Biol Chem, 2000, 275: 16382-16389

57 Heath H, 3rd, Odelberg S, Jackson CE, Teh BT, Hayward N, Larsson C, Buist NR, Krapcho KJ, Hung BC, Capuano IV, Garrett JE, Leppert MF. Clustered inactivating mutations and benign polymorphisms of the calcium receptor gene in familial benign hypocalciuric hypercalcemia suggest receptor functional domains. J Clin Endocrinol Metab, 1996, 81: 1312-1317

$58 \mathrm{Hu}$ J, McLarnon SJ, Mora S, Jiang J, Thomas C, Jacobson KA, Spiegel AM. A region in the seven-transmembrane domain of the human $\mathrm{Ca} 2+$ receptor critical for response to $\mathrm{Ca}^{2+}$. J Biol Chem, 2005, 280: 5113-5120

59 Pin JP, Galvez T, Prezeau L. Evolution, structure, and activation mechanism of family 3/C G-protein-coupled receptors. Pharmacol Ther, 2003, 98: 325-354

60 Ray K, Fan GF, Goldsmith PK, Spiegel AM. The carboxyl terminus of the human calcium receptor. Requirements for cell-surface expression and signal transduction. J Biol Chem, 1997, 272: 31355-31361

61 Awata H, Huang C, Handlogten ME, Miller RT. Interaction of the calcium-sensing receptor and filamin, a potential scaffolding protein. J Biol Chem, 2001, 276: 34871-34879

62 Hjalm G, MacLeod RJ, Kifor O, Chattopadhyay N, Brown EM. Filamin-A binds to the carboxyl-terminal tail of the calcium-sensing receptor, an interaction that participates in CaR-mediated activation of mitogen-activated protein kinase. J Biol Chem, 2001, 276: 34880-34887

63 Bai M, Trivedi S, Lane CR, Yang Y, Quinn SJ, Brown EM. Protein kinase $\mathrm{C}$ phosphorylation of threonine at position 888 in $\mathrm{Ca}^{2+} \mathrm{O}-$ sensing receptor $(\mathrm{CaR})$ inhibits coupling to $\mathrm{Ca}^{2+}$ store release. J Biol Chem, 1998, 273: 21267-21275

64 Bosel J, John M, Freichel M, Blind E. Signaling of the human calcium-sensing receptor expressed in HEK293-cells is modulated by protein kinases A and C. Exp Clin Endocrinol Diabetes, 2003, 111: 21-26

65 Stepanchick A, McKenna J, McGovern O, Huang Y, Breitwieser GE. Calcium sensing receptor mutations implicated in pancreatitis and idiopathic epilepsy syndrome disrupt an arginine-rich retention motif. Cell Physiol Biochem, 2010, 26: 363-374

$66 \mathrm{Hu}$ J, Spiegel AM. Naturally occurring mutations of the extracellular $\mathrm{Ca}^{2+}$-sensing receptor: implications for its structure and function. Trends Endocrinol Metab, 2003, 14: 282-288

67 Silve C, Petrel C, Leroy C, Bruel H, Mallet E, Rognan D, Ruat M. Delineating a $\mathrm{Ca}^{2+}$ binding pocket within the venus flytrap module of the human calcium-sensing receptor. J Biol Chem, 2005, 280: 37917-37923

68 Huang Y, Zhou Y, Yang W, Butters R, Lee HW, Li S, Castiblanco A, Brown EM, Yang JJ. Identification and dissection of $\mathrm{Ca}(2+)$-binding sites in the extracellular domain of $\mathrm{Ca}(2+)$-sensing receptor. J Biol Chem, 2007, 282: 19000-19010

69 Huang Y, Zhou Y, Castiblanco A, Yang W, Brown EM, Yang JJ. Multiple $\mathrm{Ca}(2+)$-binding sites in the extracellular domain of the $\mathrm{Ca}(2+)$-sensing receptor corresponding to cooperative $\mathrm{Ca}(2+)$ response. Biochemistry, 2009, 48: 388-398

70 Zhang C, Huang Y, Jiang Y, Mulpuri N, Wei L, Hamelberg D, Brown EM, Yang JJ. Identification of an L-phenylalanine binding site enhancing the cooperative responses of the calcium-sensing receptor to calcium. J Biol Chem, 2014, 289: 5296-5309

71 Hu J, Reyes-Cruz G, Chen W, Jacobson KA, Spiegel AM. Identification of acidic residues in the extracellular loops of the seven-transmembrane domain of the human $\mathrm{Ca}^{2+}$ receptor critical for response to $\mathrm{Ca}^{2+}$ and a positive allosteric modulator. J Biol Chem, 2002, 277: 46622-46631

72 Conigrave AD, Mun HC, Brennan SC. Physiological significance of L-amino acid sensing by extracellular $\mathrm{Ca}(2+)$-sensing receptors. $\mathrm{Bi}$ ochem Soc Trans, 2007, 35: 1195-1198

73 Conigrave AD, Quinn SJ, Brown EM. L-amino acid sensing by the extracellular $\mathrm{Ca}^{2+}$-sensing receptor. Proc Natl Acad Sci USA, 2000, 97: 4814-4819

74 Breitwieser GE. Calcium sensing receptors and calcium oscillations: calcium as a first messenger. Curr Top Dev Biol, 2006, 73: 85-114

75 Zhang Z, Qiu W, Quinn SJ, Conigrave AD, Brown EM, Bai M. Three adjacent serines in the extracellular domains of the $\mathrm{CaR}$ are required for L-amino acid-mediated potentiation of receptor function. J Biol Chem, 2002, 277: 33727-33735

76 Mun HC, Franks AH, Culverston EL, Krapcho K, Nemeth EF, Conigrave $\mathrm{AD}$. The Venus Fly Trap domain of the extracellular $\mathrm{Ca}^{2+}$-sensing receptor is required for L-amino acid sensing. $\mathrm{J}$ Biol Chem, 2004, 279: 51739-51744

77 Mun HC, Culverston EL, Franks AH, Collyer CA, Clifton-Bligh RJ, Conigrave AD. A double mutation in the extracellular $\mathrm{Ca}^{2+}$-sensing receptor's venus flytrap domain that selectively disables L-amino acid sensing. J Biol Chem, 2005, 280: 29067-29072

78 Petrel C, Kessler A, Dauban P, Dodd RH, Rognan D, Ruat M. Positive and negative allosteric modulators of the $\mathrm{Ca}^{2+}$-sensing receptor interact within overlapping but not identical binding sites in the transmembrane domain. J Biol Chem, 2004, 279: 18990-18997

79 Miedlich SU, Gama L, Seuwen K, Wolf RM, Breitwieser GE. Homology modeling of the transmembrane domain of the human calcium sensing receptor and localization of an allosteric binding site. $\mathrm{J}$ Biol Chem, 2004, 279: 7254-7263

80 Conigrave AD, Franks AH, Brown EM, Quinn SJ. L-amino acid sensing by the calcium-sensing receptor: a general mechanism for coupling protein and calcium metabolism? Eur J Clin Nutr, 2002, 56: 1072-1080

81 Conigrave AD, Brown EM. Taste receptors in the gastrointestinal tract. II. L-amino acid sensing by calcium-sensing receptors: implications for GI physiology. Am J Physiol Gastrointest Liver Physiol, 2006, 291: G753-761

82 Conigrave AD, Quinn SJ, Brown EM. Cooperative multi-modal sensing and therapeutic implications of the extracellular $\mathrm{Ca}(2+)$ sensing receptor. Trends Pharmacol Sci, 2000, 21: 401-407

83 McArthur KE, Isenberg JI, Hogan DL, Dreier SJ. Intravenous infu- 
sion of L-isomers of phenylalanine and tryptophan stimulate gastric acid secretion at physiologic plasma concentrations in normal subjects and after parietal cell vagotomy. J Clin Invest, 1983, 71: 1254-1262

84 Broadhead GK, Mun H, Avlani VA, Jourdon O, Church WB, Christopoulos A, Delbridge L, Conigrave AD. Allosteric modulation of the calcium-sensing receptor by $\gamma$-glutamyl peptides: inhibition of PTH secretion, suppression of intracellular cAMP levels, and a common mechanism of action with L-amino acids. J Biol Chem, 2011, 286: 8786-8797

85 Pi M, Spurney RF, Tu Q, Hinson T, Quarles LD. Calcium-sensing receptor activation of rho involves filamin and rho-guanine nucleotide exchange factor. Endocrinology, 2002, 143: 3830-3838

86 Rey O, Young SH, Yuan J, Slice L, Rozengurt E. Amino acid-stimulated $\mathrm{Ca}^{2+}$ oscillations produced by the $\mathrm{Ca}^{2+}$-sensing receptor are mediated by a phospholipase C/inositol 1,4,5-trisphosphateindependent pathway that requires G12, Rho, filamin-A, and the actin cytoskeleton. J Biol Chem, 2005, 280: 22875-22882

87 Huang C, Wu Z, Hujer KM, Miller RT. Silencing of filamin A gene expression inhibits $\mathrm{Ca}^{2+}$-sensing receptor signaling. FEBS Lett, 2006, 580: $1795-1800$

88 Zhang M, Breitwieser GE. High affinity interaction with filamin A protects against calcium-sensing receptor degradation. J Biol Chem, 2005, 280: 11140-11146

89 Huang C, Sindic A, Hill CE, Hujer KM, Chan KW, Sassen M, Wu Z, Kurachi Y, Nielsen S, Romero MF, Miller RT. Interaction of the $\mathrm{Ca}^{2+}$-sensing receptor with the inwardly rectifying potassium channels Kir4.1 and Kir4.2 results in inhibition of channel function. Am J Physiol Renal Physiol, 2007, 292: F1073-1081

90 Huang Y, Niwa J, Sobue G, Breitwieser GE. Calcium-sensing receptor ubiquitination and degradation mediated by the E3 ubiquitin ligase dorfin. J Biol Chem, 2006, 281: 11610-11617

91 McCullough J, Clague MJ, Urbe S. AMSH is an endosomeassociated ubiquitin isopeptidase. J Cell Biol, 2004, 166: 487-492

92 Herrera-Vigenor F, Hernandez-Garcia R, Valadez-Sanchez M, Vazquez-Prado J, Reyes-Cruz G. AMSH regulates calcium-sensing receptor signaling through direct interactions. Biochem Biophys Res Commun, 2006, 347: 924-930

93 Reyes-Ibarra AP, Garcia-Regalado A, Ramirez-Rangel I, Esparza-Silva AL, Valadez-Sanchez M, Vazquez-Prado J, Reyes-Cruz G. Calcium-sensing receptor endocytosis links extracellular calcium signaling to parathyroid hormone-related peptide secretion via a Rab11a-dependent and AMSH-sensitive mechanism. Mol Endocrinol, 2007, 21: 1394-1407

94 DeWire SM, Ahn S, Lefkowitz RJ, Shenoy SK. Beta-arrestins and cell signaling. Annu Rev Physiol, 2007, 69: 483-510

95 Morfis M, Christopoulos A, Sexton PM. RAMPs: 5 years on, where to now? Trends Pharmacol Sci, 2003, 24: 596-601

96 Bouschet T, Martin S, Henley JM. Receptor-activity-modifying proteins are required for forward trafficking of the calcium-sensing receptor to the plasma membrane. J Cell Sci, 2005, 118: 4709-4720

97 Shenoy SK, Lefkowitz RJ. beta-Arrestin-mediated receptor trafficking and signal transduction. Trends Pharmacol Sci, 2011, 32: 521-533

98 Shukla AK, Xiao K, Lefkowitz RJ. Emerging paradigms of beta-arrestin-dependent seven transmembrane receptor signaling. Trends Biochem Sci, 2011, 36: 457-469

99 Skach WR. Cellular mechanisms of membrane protein folding. Nat Struct Mol Biol, 2009, 16: 606-612

100 Ulloa-Aguirre A, Conn PM. Targeting of G protein-coupled receptors to the plasma membrane in health and disease. Front Biosci (Landmark Ed), 2009, 14: 973-994

101 Stepanchick A, Breitwieser GE. The cargo receptor p24A facilitates calcium sensing receptor maturation and stabilization in the early secretory pathway. Biochem Biophys Res Commun, 2010, 395: $136-140$
102 Zhuang X, Chowdhury S, Northup JK, Ray K. Sar1-dependent trafficking of the human calcium receptor to the cell surface. Biochem Biophys Res Commun, 2010, 396: 874-880

103 Zhuang X, Adipietro KA, Datta S, Northup JK, Ray K. Rab1 small GTP-binding protein regulates cell surface trafficking of the human calcium-sensing receptor. Endocrinology, 2010, 151: 5114-5123

104 Grant MP, Stepanchick A, Cavanaugh A, Breitwieser GE. Agonist-driven maturation and plasma membrane insertion of calcium-sensing receptors dynamically control signal amplitude. Sci Signal, 2011, 4: ra78

105 Blum R, Pfeiffer F, Feick P, Nastainczyk W, Kohler B, Schafer KH, Schulz I. Intracellular localization and in vivo trafficking of $\mathrm{p} 24 \mathrm{~A}$ and p23. J Cell Sci, 1999, 112(Pt 4): 537-548

106 Strating JR, Martens GJ. The p24 family and selective transport processes at the ER-Golgi interface. Biol Cell, 2009, 101: 495-509

107 Arulpragasam A, Magno AL, Ingley E, Brown SJ, Conigrave AD, Ratajczak T, Ward BK. The adaptor protein 14-3-3 binds to the calcium-sensing receptor and attenuates receptor-mediated Rho kinase signalling. Biochem J, 2012, 441: 995-1006

108 Jung SY, Kwak JO, Kim HW, Kim DS, Ryu SD, Ko CB, Cha SH. Calcium sensing receptor forms complex with and is up-regulated by caveolin-1 in cultured human osteosarcoma (Saos-2) cells. Exp Mol Med, 2005, 37: 91-100

109 Kifor O, Kifor I, Moore FD Jr., Butters RR Jr., Brown EM. $\mathrm{m}$-Calpain colocalizes with the calcium-sensing receptor $(\mathrm{CaR})$ in caveolae in parathyroid cells and participates in degradation of the CaR. J Biol Chem, 2003, 278: 31167-31176

110 Sun J, Murphy E. Calcium-sensing receptor: a sensor and mediator of ischemic preconditioning in the heart. Am J Physiol Heart Circ Physiol, 2010, 299: H1309-1317

$111 \mathrm{Tu}$ CL, Chang W, Bikle DD. The calcium-sensing receptor-dependent regulation of cell-cell adhesion and keratinocyte differentiation requires Rho and filamin A. J Invest Dermatol, 2011, 131: $1119-1128$

112 Lorenz S, Frenzel R, Paschke R, Breitwieser GE, Miedlich SU. Functional desensitization of the extracellular calcium-sensing receptor is regulated via distinct mechanisms: role of $\mathrm{G}$ protein-coupled receptor kinases, protein kinase C and beta-arrestins. Endocrinology, 2007, 148: 2398-2404

113 Pi M, Oakley RH, Gesty-Palmer D, Cruickshank RD, Spurney RF, Luttrell LM, Quarles LD. Beta-arrestin- and G protein receptor kinase-mediated calcium-sensing receptor desensitization. Mol Endocrinol, 2005, 19: 1078-1087

114 Nesbit MA, Hannan FM, Howles SA, Reed AA, Cranston T, Thakker CE, Gregory L, Rimmer AJ, Rust N, Graham U, Morrison PJ, Hunter SJ, Whyte MP, McVean G, Buck D, Thakker RV. Mutations in AP2S1 cause familial hypocalciuric hypercalcemia type 3. Nat Genet, 2013, 45: 93-97

115 Zhuang X, Northup JK, Ray K. Large putative PEST-like sequence motif at the carboxyl tail of human calcium receptor directs lysosomal degradation and regulates cell surface receptor level. J Biol Chem, 2012, 287: 4165-4176

116 Hanyaloglu AC, von Zastrow M. Regulation of GPCRs by endocytic membrane trafficking and its potential implications. Annu Rev Pharmacol Toxicol, 2008, 48: 537-568

117 Moore CA, Milano SK, Benovic JL. Regulation of receptor trafficking by GRKs and arrestins. Annu Rev Physiol, 2007, 69: 451-482

118 Ardley HC, Robinson PA. E3 ubiquitin ligases. Essays Biochem, 2005, 41: 15-30

119 Geoffrey N. Hendy VG, Lucie Canaff. Calcium-sensing receptor and associated diseases. In: Progress in Molecular Biology and Translational Science. Vol. 89. Elsevier Inc., 2009. 31-95

120 Thakker RV. Diseases associated with the extracellular calcium-sensing receptor. Cell Calcium, 2004, 35: 275-282

121 Kemp EH, Gavalas NG, Krohn KJ, Brown EM, Watson PF, Weetman AP. Activating autoantibodies against the calcium-sensing re- 
ceptor detected in two patients with autoimmune polyendocrine syndrome type 1. J Clin Endocrinol Metab, 2009, 94: 4749-4756

122 Kemp EH, Gavalas NG, Akhtar S, Krohn KJ, Pallais JC, Brown EM, Watson PF, Weetman AP. Mapping of human autoantibody binding sites on the calcium-sensing receptor. J Bone Miner Res, 2010, 25: $132-140$

123 Ward BK, Magno AL, Blitvich BJ, Rea AJ, Stuckey BG, Walsh JP, Ratajczak T. Novel mutations in the calcium-sensing receptor gene associated with biochemical and functional differences in familial hypocalciuric hypercalcaemia. Clin Endocrinol (Oxf), 2006, 64: 580-587

124 Hendy GN, D’Souza-Li L, Yang B, Canaff L, Cole DE. Mutations of the calcium-sensing receptor (CASR) in familial hypocalciuric hypercalcemia, neonatal severe hyperparathyroidism, and autosomal dominant hypocalcemia. Hum Mutat, 2000, 16: 281-296

125 Watanabe S, Fukumoto S, Chang H, Takeuchi Y, Hasegawa Y, Okazaki R, Chikatsu N, Fujita T. Association between activating mutations of calcium-sensing receptor and Bartter's syndrome. Lancet, 2002, 360: 692-694
126 Hannan FM, Nesbit MA, Zhang C, Cranston T, Curley AJ, Harding B, Fratter C, Rust N, Christie PT, Turner JJ, Lemos MC, Bowl MR, Bouillon R, Brain C, Bridges N, Burren C, Connell JM, Jung H, Marks E, McCredie D, Mughal Z, Rodda C, Tollefsen S, Brown EM, Yang JJ, Thakker RV. Identification of 70 calcium-sensing receptor mutations in hyper- and hypo-calcaemic patients: evidence for clustering of extracellular domain mutations at calcium-binding sites. Hum Mol Genet, 2012, 21: 2768-2778

127 Rogers A, Nesbit MA, Hannan FM, Howles SA, Gorvin CM, Cranston T, Allgrove J, Bevan JS, Bano G, Brain C, Datta V, Grossman AB, Hodgson SV, Izatt L, Millar-Jones L, Pearce SH, Robertson L, Selby PL, Shine B, Snape K, Warner J, Thakker RV. Mutational analysis of the adaptor protein 2 sigma subunit (AP2S1) gene: search for autosomal dominant hypocalcemia type 3 (ADH3). J Clin Endocrinol Metab, 2014, 99: E1300-1305

128 Strauss A, Bitsch F, Cutting B, Fendrich G, Graff P, Liebetanz J, Zurini M, Jahnke W. Amino-acid-type selective isotope labeling of proteins expressed in Baculovirus-infected insect cells useful for NMR studies. J Biomol NMR, 2003, 26: 367-372

Open Access This article is distributed under the terms of the Creative Commons Attribution License which permits any use, distribution, and reproduction in any medium, provided the original author(s) and source are credited. 